\title{
Research on Principles and Strategies of Business English Translation based on Functional Perspective
}

\author{
Liyuan Liu ${ }^{1, a}$ \\ ${ }^{1}$ Jilin Agricultural Science and Technology University, 132101, Jilin City, China. \\ aliyuan-liu@126.com
}

Keywords: Business English translation, functional perspective, principles and strategies

\begin{abstract}
Business English translation has become more important in international economy and trade with rapid development of economic globalization. Business English translation is categorized into English for Special Purpose, so its features are different from those of other kinds of translations such as literary translation. Therefore, there is much limitation to the application of traditional translation theories. In this paper attempts to take Skopos, Communicative Translation and Functional Equivalence Theory to analyze business English translation from functional perspective. Meanwhile also employs several was pointed out that the functional theories can be guidance to business English translation and put forward some principles and strategies suitable and useful for business English translation.
\end{abstract}

\section{Introduction}

With the rapid development of our society, economic globalization, business English translation of an important position in the global economic sphere gradually increased. Business English which are mainly used in international trade, is a special language, so there is a big difference in business English translation and other forms of translation. Business English used in the economic environment has become a trend in the current stage of development, since the application of business English in the form of trade among multiple letters appear, so the translation process should pay more attention to its practical, realistic and holistic approach, which ensure they comply with certain principles and strategies in translation in progress.

Business English translation functionality that take different forms depending on business text, is the purpose of trade is based on different trade sender, take the form of different trading strategies. The most common forms of communication such as a letter in the economic process, business contracts, trade between the two sides meeting summary and product advertising information, and so on. Business Translation of belonging to the application areas, the traditional form of translation literature has a greater difference, translation aims to reach the final translation in their cultural environment in one or more forms of communicative function. In the translation process, the translator should ensure standardization on the basis of the original translation of the original in business dealings by the presence of interaction purpose, as the basis for the translation of core standards. Found in translation suitable method to translate so faithful to the original, without departing from the original text, in order to achieve the ultimate goal of communication. Business English translation functionality to break the traditional mode of translation, and the overthrow of the "equivalence translation theory" of the constraints, the translation of the work presented in a new cultural context which, in order to effectively spread.

\section{Situation business English abroad}

For Business English translation has functional characteristics, status of domestic and international business from the English translation for analysis, presented as the importance of business English translation. Business English translation of research presented at a rapid pace in the academic field in which its research perspective, a wide field of research and uneven distribution of the major 
characteristics of such experts and scholars eager to study it, to strive in business English translation Research academic status. Some foreign countries for higher business English translation of the degree of attention, researchers believe that the effectiveness of its business English translation can ensure its effective use in practice, for example, the largest US mobile phone vendors Apple, its authorized stores in the world very large, mostly in the form of business letters appear in the process engaged in trade, effective business English translation can provide more opportunities for cooperation, so as to enhance economic efficiency. And in the business of translation studies, many experts and scholars to participate in research work carried out, it is in terms of the number of research papers in the past several times, become more international level in research quality.

\section{Features business English text}

Business English vocabulary specialization. Features Business English text is the most important feature in the form of specialized vocabulary, we tend to use more technical terms in business English translation process, having business meaning of common words and compound words, abbreviations, and so on. Technical terms, is a unique business English vocabulary, a huge number, but also has a strong professional, this particular word on relatively specific meaning of the expression, not too much extended meaning. Such as repeat order, this word can only be re-ordering in business English translation, and confirmed irrevocable term translation in business English in order to protect against irrevocable letter of credit; common vocabulary and complex words have meanings in business mainly refers to the Business English general terms that appear in the form of a combination of vocabulary and general vocabulary and become, in the course of its use, relatively easy to translate, and there is no extended meaning, can effectively ensure the viability of business English translation; and abbreviated words that speaks specific words to simple initials instead of forms, such as B / L bill of lading in the business translated into English translation. This form is more common in trade, therefore, in the process of implementing business English translation, the utilization rate more.

Syntactic pattern of Business English is one of its characteristics, in the implementation process of translation or in the form of a fixed sentence based on the sentence applied. Moreover, in commercial contracts often use long sentences, therefore, frequently of long sentences is particularly important, long sentence statement generally dominated, such manifestations can effectively express contract itself has integrity, more logical sex. Business Letters and sentences often expressed in the form of exhibits dapper, using business English translation in the language more concise, which to some extent reduces the error rate translation. Its syntax is simple, reflected in the effective use of spoken and written language, by taking certain precautions to avoid possible bureaucratic, cumbersome sentence. It says this is because the business itself time and stress efficiency, while the business version of its best form of expression, a simple expression of form and expression effectively grasp the content is very important. In the syntax above, showed longer sentence form, because it has more features long sentences, the business advantages of the text will appear across a wide segment of long sentences, attributive clause and adverbial clause in the form of more long sentences.

On Business English Texts presented is characterized by short and sweet, and there are some fixed format in the text, showing text concise, compact form, in terms of their overall grasp of this article is the formal business English most distinctive feature. Business English Texts which can be divided into the following categories: business letters, meeting minutes, forms of advertising, the report specification, bidding letter of intent, commercial contracts and other business-related documents, and so on. Discourse on the specific genre presents different requirements, there is a specific form of the structure. For example, in business contracts which, having formatted text structure characteristics, the expression of entry, standardized terminology, content integrity, targeted, so that the chapters more rigor. The agreement has a binding contract laws and regulations in trade which has certain constraints, therefore, it is in the process of translation in order to avoid unnecessary misunderstanding and ambiguous wording, rendered in strict formation process text and accurate feature. Thereby reflecting the short and sweet Business English Texts. 


\section{Business English translation theory and practice the principles and strategies}

Business English translation theory and practice principles to follow. For business translation theory, the Western countries Eugene - Uida equivalence translation theory is the most authoritative guide to business English translation of guiding principles. That the focus of its business English translation not only reflected in the performance of formal language, the wording should be prominent features highlight the reader's response to translation. The implication, requirements on language function with the original on the other, this theory for business English translation of great significance. During the research for this article, according to Business English formal features, business English translation in order to achieve the accuracy, functionality, should follow the following principles:

To follow the principle of the complete text. That is, during the course of business English translation stays true to its original principles, not only to reflect the original ideological content presented should be considered to the presentation in its original language in the course of the narrative style. The reason to follow this principle, the text of which is due in the business applications used for business letters, business contracts, insurance, financial and other aspects, in these applications exhibit the above content with a certain seriousness, put an end to the translator in the translation of random which performed. Once the original message errors or omissions caused by the phenomenon of trade for economic losses caused immeasurable.

Follow the norms unifying principle. Follow the normative principles refers to language translation requirements and the way in drafting process must be in accordance with the norms of business documents, implication, translators rendered the article as professionals in the field of economy and trade as written. Application of terminology and expression sentence in the article, must comply with regulatory requirements for business instruments. In the translation process in the event of technical terms difficult to understand, the first time to conduct inspection and so understanding.

Strategy Skills Business English Translation. Business outside the English translation to follow certain principles, but also have a certain strategy skills. First, the accurate translation of terminology is one of the most important strategy. Accurate and standardized text translation of business jargon is extra attention in the process of translation problems. Business texts which are used for application of business letters, business contracts, insurance, financial and other aspects of the area covered is more extensive, including economic, trade, law, etc., and in these areas the existence of different terminology, translation needs more attention. For example, confirm the word in the translation there is a different meaning, and confirmed letter of credit confirmation two meanings.

\section{Business English reading motivation and attitudes influence the selection and use of reading strategies}

Author interviews found that some students can consciously learn reading strategies and try to use these strategies in reading. Conversely, some students is not strong sense of strategy, as long as they expanded the amount of reading and more questions, the results will improve business English. Some interviewees are not interested in business English, rarely take the initiative to read, learning to cope with the exam. These students' English scores and reading levels are low, which also shows the catalytic role of motivation and interest in learning. Further Business English Reading purposeful students are more active use of reading strategies. Improve the teaching management system, stimulate college students' learning motivation. Training for policy from students before and after comparison can be seen, where my school college students a serious lack of motivation to learn. After entering the school, the students for their future of a confused, combined with the college students, and undergraduate students have always felt a big gap, relatively strong sense of inferiority, so nothing at all interested in the natural process of learning business English will not adopt a positive attitude to the use of a variety of effective strategies, frequency of use of such tactics is not high. To fundamentally change this situation, we have to improve the teaching management system, changing the examination system so that teachers play a certain amount of flexibility, autonomy and creativity 
through a variety of ways to assess students. Stimulate college students interested in business English. Because "Motivation comes from a keen interest in what they have learned something." Interview, is showing little learning initiative visitors. Therefore, to update teaching concepts, continue to implement the "learner-centered" teaching mode. Teachers in teaching should pay special attention to the "learner-centered" concept of teaching, as much as possible to create opportunities for students to participate in teaching activities, we should always pay attention to students' progress, and timely recognition, appreciation use education, establish their learning confidence. The only way to enable students to truly become the masters of learning, then actively choose their own learning strategies to improve self-learning ability to improve learning efficiency, has gradually become a social adaptation autonomous learners.

I found that students in business English reading process, there are some common issues that hinder the improvement of their reading ability, the reason is mainly the following points: 1 . Language weak foundation. Mainly that there is insufficient vocabulary and not read long complex sentences. 2. Develop a poor reading habits. The typical diet is as follows: whispered reading, silent reading, word for word reading, which greatly affect improve your reading speed. 3. Low reading comprehension. Many of the students will focus on a particular language points, ignoring the full text of the framework structure. 4. Lack of relevant expertise. Some articles appearing in professional terms often become students to read during the stumbling block. 5. Unfamiliar language documents. Students of many business articles to cite legal provisions, business contracts and other terms of difficulty in understanding, slow reading speed. In short, the reading strategies, knowledge of the language barriers and obstacles content icon.

\section{Business use cases reading strategies}

In an interview with the author the use of "sound thinking" approach to understand the different reading levels of students' reading process and application strategy, focusing on four key reading strategies: prediction, skimming, scanning reading, reasoning and the use of resource policy were survey.

Prediction: this is the use of more land policy, high scores can be predicted based on the context, but the use is not flexible enough, for example, do not realize the relationship between the title and content of the article, we do not proceed from a special business English style structure prediction . Overall, the high and low scorers on the use of this strategy was not very good. The reason is that not verify his guess, few predict the joy of success, thus affecting the next generation of prediction. 2 . Skimming and seek read: high and low scores are more to use these two strategies. Interviewers are more emphasis on finding the topic sentence of the paragraph, in order to understand the text; also attached great importance to the beginning and end of the article. 3. Reasoning: high scorer's greater use of this strategy. They have more background knowledge, they are able to use a variety of channels to understand the relevant knowledge, and scorers lack background knowledge makes their guess little success. Highest scores in the reading process can be obtained by the information content of the article, and can use existing knowledge to judge the reasoning, it is efficient reading mode is "Interaction reading" mode. 4. Resource Strategy: Almost all of the interviewees have recognized the reading process for resource policies greatly increased their motivation to learn and interest, and to some extent on the rich business knowledge, achieved one of the purposes of business English reading; However, the high and low scores are also differences, high scores and grades increase by a big margin reported them to take the initiative to read in class, but only in the lower scorers inform teachers and students before going to read related content.

Interview, that the individual students in the classroom under the teacher's guidance, can take the initiative to use newly learned strategy, but would not extracurricular, this is obviously a lack of learning consciousness and willpower is weak. Meng Yue also said: short-term training will not produce long-term effects on students, nor will they mold into a skilled user policy. Therefore, 
teachers in the usual teaching students to continue to strengthen the awareness of policy, strategy training to long-term, the long-term repeated training in order to achieve the purpose of automation.

Interviews also show that training students of different strategies different attitude, different levels of students to master the four strategies are not the same. $80 \%$ of the students to read the policy in favor of the main line of teaching methods. They believe that this training method can "make teaching achieve a multiplier effect," "can enhance students' self-confidence, a sense of students", give full play to the role of non-intelligence factors. Students also "want to continue in the future." But $20 \%$ of the students choose and use reading strategies difficult; especially in the exam. Lower grades of the students that their greatest gains is the strategy of using resources, by getting more effective material, they are business English learning motivation significantly improved. Vesicle's corpus to improve business English reading is helpful.

Further interviews for three scores decreased greatly student analyzes the reasons, they do not think the whole experience for learning, some of them to participate in various school activities, distracted. There are students training policy did not cause enough attention, leading to the end of the test results showed that the test does not work for them, it is necessary in teaching students to guide, pay attention to learner differences, and for a variety of school activities should be reasonable to treat so that they have clear learning objectives.

\section{Summary}

Business English translation skills strategy is not only reflected in the correct professional terminology, but also the process of translation based on the original language style. In the process of translating business texts process to grasp the business style of the text in its original tone by overall grasp the tone of the original style of presentation, thereby reproducing the characteristics of the original features. For example, business letter, the text of which belong to the formal register, the application of this article which should focus on rigorous wording grasp tactful tone style, courtesy of strengthening the degree of attention. Therefore, when the business translation process, we should pay special attention to reflect the original ceremonial tone. For example, in China's domestic business correspondence letters, the use of your company, courtesy, please, etc. King speech. In business English letter, courtesy action more frequently, and more emphasis on the exchange of letters with each other effective linkages to promote trade, therefore, appropriate and effective action to restore its original etiquette is extremely important.

Through the specific content of this study to understand the necessity of business English translation rendered, and analyze the status of specific applications by domestic and international business English translation. In this process, the characteristics of business English text presented one by one, can be targeted to study, and to ensure that the process of translation in business English, follow certain principles. So difficult to find functional theory is the basis of business English translation, with guidance, can effectively guide practical application in business English translation, presenting a study from a functional point of view of business English translation principles and strategies to effectively improve business English translation of an important role.

\section{References}

1. LIU Dan-dan Strategy reading. Chinese English learners. Foreign language, 2002, (6).

2. Liu public law. On ESP attributes corresponding to the teaching method. Teaching of Foreign Languages, 2001, (12).

3. Liu Yichun learning successful and unsuccessful use of English reading research policy differences. Foreign Language Teaching, 2002, (3).

4. Lin Tian Lake. Development of Business English subjects of Xiamen University, 2001, (4). 
5. Lei Chunlin. On language teaching content-based business. International Business Research, 2006, (6).

6. Experimental study of Meng Yue college English reading strategies. Foreign Language Teaching, 2004, (4).

7. Ma Guanghui difference of high and low packet grouping students in learning strategies. Western sector, 1997 (2).

8. Business English course objectives and teaching principles. Western intellectual circles Ruan Ji University, 2005, (2). 